\title{
SCIENTIFIC TRAINING OF SPORTS MEDICINE FOR BALANCE OF KNEE JOINT MUSCLE STRENGTH OF ATHLETES
}

\author{
TREINAMENTO CIENTÍFICO DE MEDICINA ESPORTIVA PARA EQUILIBRIO DA FORÇA MUSCULARDA \\ ARTICULAÇÃODO JOELHODEATLETAS \\ ENTRENAMIENTO CIENTÍFICO DE LA MEDICINA DEPORTIVA PARA EL EQUILIBRIO DE LA FUERZA \\ MUSCULARDE LAARTICULACIÓN DE LARODILLA DE LOS ATLETAS
}

Yanhua Men ${ }^{1}$ (D)

(Physical Education Professional)

1. Jilin Sport University,

Changchun, China.

\section{Correspondence:}

ilin Sport University, Changchun, 130000, China

465984959@qq.com

\begin{abstract}
Introduction: As skiers need to complete their movements in high mountains and snow, the athlete's landing's stability is directly related to the movement's success. The stable landing action wins high scores for the athletes' participating actions and protects their safety. Objective: This article analyzes the characteristics of lower limb muscle strength and static balance ability of female freestyle skiing aerials athletes to provide athletes with targeted strength training, evaluation of muscle effects after training, and athlete selection to provide a scientific basis valuable Theoretical reference. Methods: The paper uses isokinetic testing and balance testing methods to study the characteristics of the hip and knee flexor and extensor strengths of the Chinese great female freestyle skiing aerials athletes and the static balance characteristics in four standing positions. Results: The right flexor-extensor force, flexor-extensor force ratio, and average power value of the right hip joint were slightly greater than the left flexor power. The left and right knee joint extensor unit peak weight moments and the left and right average power values were all four indicators. Greater than the flexor, at different test speeds of $60 \% \mathrm{~s}$ (slow speed) and $240 \% \mathrm{~s}$ (fast), the peak flexion and extension torque per unit weight, the average power of flexion and extension, the force of flexion and extension, and the average power appear with the increase of the test speed as a significant difference. Conclusions: The research in the thesis recommends reasonable weight control and balanced training of muscle strength, using the condition of moderately increasing exercise speed, to strengthen the training of lower limb extensor strength, provide targeted strength training for athletes, evaluate the muscle effect after training and providing the scientific basis and valuable theoretical reference. Level of evidence Il; Therapeutic studies - investigation of treatment results.
\end{abstract}

Keywords: Skiing; Athletes; Static balance ability; Water sports; Muscle development.

\section{RESUMO}

Introdução: Como os esquiadores precisam completar seus movimentos em altas montanhas e neve, a estabilidade de pouso do atleta está diretamente relacionada ao sucesso do movimento. A ação de pouso constante ganha altas pontuações para os participantes e protege sua segurança. Objetivo: este artigo discute as características da força muscular das extremidades inferiores e habilidade de equilibrio estático de atletas de esqui estilo livre para fornecer aos atletas treinamento de força específico e avaliação pós-treino dos efeitos musculares em atletas selecionados para fornecer uma base científica de referência teórica valiosa. Métodos: 0 artigo usa testes isocinéticos e métodos de teste de equilíbrio para estudar as características de força dos flexores e extensores de quadril ejoelho de grandes atletas chinesas de esqui estilo livre e as características de equilibrio estático em quatro posições de pé. Resultados: A força flexor-extensora direita, a relação da força flexor-extensora e o valor médio da potência da articulação do quadril direito foram ligeiramente maiores do que a potência do flexor esquerdo. Os momentos máximos de peso da unidade extensora da articulação do joelho esquerdo e direito e os valores médios das potências esquerda e direita foram os quatro indicadores. Maior que o flexor, em diferentes velocidades de teste de $60 \%$ s (velocidade lenta) e $240 \%$ s (rápido), o torque máximo de flexão e extensão por unidade de peso, a força média de flexão e extensão, a força de flexão e extensão, e a potência média aparece com o aumento da velocidade de teste como uma diferença significativa. Conclusões: A pesquisa na tese recomenda o controle de peso razoável e o treinamento de força muscular balanceado, utilizando a condição de aumentar moderadamente a velocidade do exercício, para fortalecer o treinamento de força extensora de membros inferiores, fornecer treinamento de força especifico para atletas, avaliando o efeito muscular após formar e fornecer a base científica e um valioso referencial teórico. Nível de evidência Il; Estudos terapêuticos- investigação dos resultados do tratamento.

Descritores: Esqui; Atletas; Capacidade de equilibrio estático; Esportes aquáticos; Desenvolvimento muscular.

\section{RESUMEN}

Introducción: Como los esquiadores necesitan completar sus movimientos en alta montaña y nieve, la estabilidad del aterrizaje del atleta está directamente relacionada con el éxito del movimiento. La acción de aterrizaje 
estable gana puntuaciones altas para las participantes y protege su seguridad. Objetivo: Este artículo analiza las características de la fuerza muscular de las extremidades inferiores y la capacidad de equilibrio estático de las atletas de esquí de estilo libre para proporcionar a los atletas un entrenamiento de fuerza específico y una evaluación de los efectos musculares después del entrenamiento en atletas seleccionados para proporcionar una base científica de referencia teórica valiosa. Métodos: El artículo utiliza pruebas isocinéticas y métodos de prueba de equilibrio para estudiar las características de la fuerza de los flexores y extensores de cadera y rodilla de las grandes atletas chinas de esquíde estilo libre femenino y las características del equilibrio estático en cuatro posiciones de pie. Resultados: La fuerza flexora-extensora derecha, la relación de fuerza flexora-extensora y el valor de potencia promedio de la articulación de la cadera derecha fueron ligeramente mayores que la potencia del flexor izquierdo. Los momentos de peso máximo de la unidad extensora de la articulación de la rodilla izquierda y derecha y los valores de potencia promedio izquierda y derecha fueron los cuatro indicadores. Mayor que el flexor, a diferentes velocidades de prueba de $60 \%$ s (velocidad lenta) y $240 \%$ s (rápido), el par máximo de flexión y extensión por unidad de peso, la potencia promedio de flexión y extensión, la fuerza de flexión y extensión, y la potencia media aparecen con el aumento de la velocidad de prueba como una diferencia significativa. Conclusiones: La investigación en la tesis recomienda un control de peso razonable y un entrenamiento equilibrado de la fuerza muscular, utilizando la condición de aumentar moderadamente la velocidad del ejercicio, para fortalecer el entrenamiento de la fuerza extensora de las extremidades inferiores, proporcionar entrenamiento de fuerza especifico para los atletas, evaluar el efecto muscular después del entrenamiento y proporcionar la base científica y una valiosa referencia teórica. Nivel de evidencia ll; Estudios terapéuticos- investigación de los resultados del tratamiento.

Descriptores: Esquí; Atletas; Capacidad de equilibrio estático; Deportes acuáticos; Desarrollo de músculos.

\section{INTRODUCTION}

Freestyle skiing aerials belong to difficult and beautiful sports and is the perfect display of human skiing skills and gymnastic art. Freestyle skiing aerials are composed of four parts: assist sliding, take-off, air, and landing. Since the action needs to be completed in the mountains and snow, the athlete's landing's stability is directly related to the success of the action. The stable landing action wins high scores for the athletes' participating actions and protects the athletes' safety. The stability of an athlete's landing is related to the completed movement's quality, whether the landing movement conforms to the principles of mechanics and the body's balance ability. The muscle strength of the lower limbs of athletes is the key to restricting the quality of movement and body balance.' Therefore, the strength of the athlete's lower limb muscles determines the air and landing posture. This article analyzes the characteristics of female freestyle skiing aerials athletes' lower limb muscle strength and static balance ability. It provides a scientific basis and valuable theoretical reference for athletes to carry out targeted strength training, evaluate muscle effects after training, and select athletes.

\section{METHOD}

\section{General information}

The experimental subjects of this study selected six national freestyle skiing aerials, female athletes. The basic situation is shown in Table 1.

Table 1. The basic situation of research subjects.

\begin{tabular}{c|c|c|c|c}
\hline Object & Height/cm & Weight/kg & Age /year old & $\begin{array}{c}\text { Training } \\
\text { years/year }\end{array}$ \\
\hline A & 160.2 & 51.7 & 25 & 13 \\
\hline B & 155.1 & 61.7 & 26 & 13 \\
\hline C & 163.6 & 62.6 & 19 & 7 \\
\hline D & 160.7 & 160.7 & 24 & 12 \\
\hline E & 160.4 & 51.8 & 22 & 11 \\
\hline F & 163.3 & 54.5 & 24 & 10 \\
\hline
\end{tabular}

\section{RESEARCH METHODS}

\section{Isokinetic test of muscle strength}

The paper uses the ISOMED2000 isokinetic test system produced in Germany to test the flexor and extensor strength of athletes' hip and knee joints. According to the relevant literature and the athlete's physical fitness and project characteristics, the test condition parameters were selected, and $60 \%$ s was selected as slow speed and $240 \%$ s as fast speed. The coach leads the team members to prepare for the test, and the time for the preparation is 15 minutes. Perform three tests at each test speed, allowing the subjects to complete the test to the best of their ability. ${ }^{2}$ Test 3 times at each speed, with 30s interval between the groups, and take the average of the 3 test results for analysis.

Test index: The maximum torque per unit weight refers to the maximum torque percentage in the body weight. The maximum torque is affected by the weight factor. The maximum torque per unit weight is considered the golden index in the isokinetic test and is commonly used in muscle strength testing. ${ }^{3}$ An indicator of flexion and extension; the maximum torque ratio of flexion and extension reflects the ratio of flexor and extensor force, the balance between the antagonistic muscles, and the stability of the joint; the total power is all the work done in a unit of time of muscle contraction; the range of joint motion is the joint flexion the angle of extension can be used to evaluate the symmetry of the left and right work of the trunk.

\section{Determination of static balance ability}

This article uses the METITUR balance test system produced in Finland. The subjects were required to warm up for 10 minutes during the test. During the test, it is required to test in 4 standing positions, and the test time is the 20s.

Open eyes bipedal support balance: the subject stands on the balance force plate with both feet, hands-on-hips, eyes looking straight ahead; open eyes bipedal linear support balance: the subject's feet stand linearly on the balance force plate (right Feet in front), hands-on-hips, 
eyes straight ahead; closed eyes and right foot support balance: lift the left foot about $20-30 \mathrm{~cm}$ above the force plate, hands-on-hips, eyes closed; closed eyes, left foot single support balance, right foot lifted on the force plate About 20 to $30 \mathrm{~cm}$ above the front, with hands-on-hips and eyes closed for 20 seconds. ${ }^{4}$ The group interval is the 30 s.

Test indicators: front and rear (Y-axis) movement distance, the distance of the human center of gravity projection point in the front and rear directions; the left and right (X-axis) movement distance, the distance of the human center of gravity projection point in the left and right directions; the speed moment, the center of gravity is on three axes The size of the closing speed.

\section{Human body static balance motion mechanics algorithm}

The human body static balance motion mechanics algorithm mainly includes two aspects: the coarse-grained signal and the multivariate sample entropy (MSE).

1. For a given time series $\{u(1), u(2), \cdots, u(N)\}$ of original signals according to the formula:

$$
y_{j}^{\tau}=1 / \tau \sum_{i=(j-1) \tau+1}^{j \tau} u_{i}(1 \leq j \leq N / \tau)
$$

Perform coarse-graining, and obtain the time series $\{y(1)\}$ when the continuous coarse-grained time series $\{y(\tau)\}, \tau$ is under the time scale factor $\tau$ as the original sequence. ${ }^{5}$ The coarse-graining process is shown in Figure 1.

2. For each scale $\tau$, calculate the MSE of the coarse-grained data $\{y(\tau)\}$. This article mainly proposes improvements to the calculation process of MSE. To calculate the MSE, according to the multivariate embedding theory, for the $\mathrm{p}$ time series $\left\{x_{k, i}\right\}_{i=1}^{n}, k=1,2, \cdots, p$, a multivariate composite delay vector is generated according to equation (2).

$$
\begin{aligned}
& \mathrm{X}_{\mathrm{m}}(i)=\left[X_{1, i}, X_{1, i+\tau_{1}}, \cdots, X_{1, i+\left(m_{1}-1\right)_{\tau 1}}, X_{2, i},\right. \\
& X_{2, i+\tau_{2}}, \cdots, X_{2, i+\left(m_{2}-1\right) \tau_{2}, \cdots, X_{P, i}}, \\
& \left.X_{P, i+\tau_{P}}, \cdots, X_{P, i+\left(m_{p}-1\right) \tau_{p}}\right]
\end{aligned}
$$

$$
d\left[X_{m}(i), X_{m}(j)\right]=\max _{l=1,2, \cdots, m}\left\{\left|y^{\tau}(i+l-1)-y^{\tau}(j+l-1)\right|\right\} \text { (3) }
$$

$$
M_{m+1}(i)=\left[m_{1}, m_{2}, \cdots m_{k+1}, \cdots, m_{p}\right](k=1,2, \cdots, p)
$$

$M_{m+1}(i)=\left[m_{1}+1, m_{2}+1, \cdots m_{k}+1, \cdots, m_{p}+1\right](k=1,2, \cdots, p)$

In formula (2), $X_{m}(i)$ is the multivariate delay vector $M=\left[m_{1}, m_{2}, \cdots m_{p}\right]$ is the embedded vector, and $\tau=\left[\tau_{1}, \tau_{2}, \cdots \tau_{p}\right]$ is the delay vector.

\section{Mathematical Statistics}

The statistical analysis of the data was processed by SPSS16.0 SOciology software package and EXCEL, using the paired-sample t-test comparison and multivariate correlation analysis in statistics.

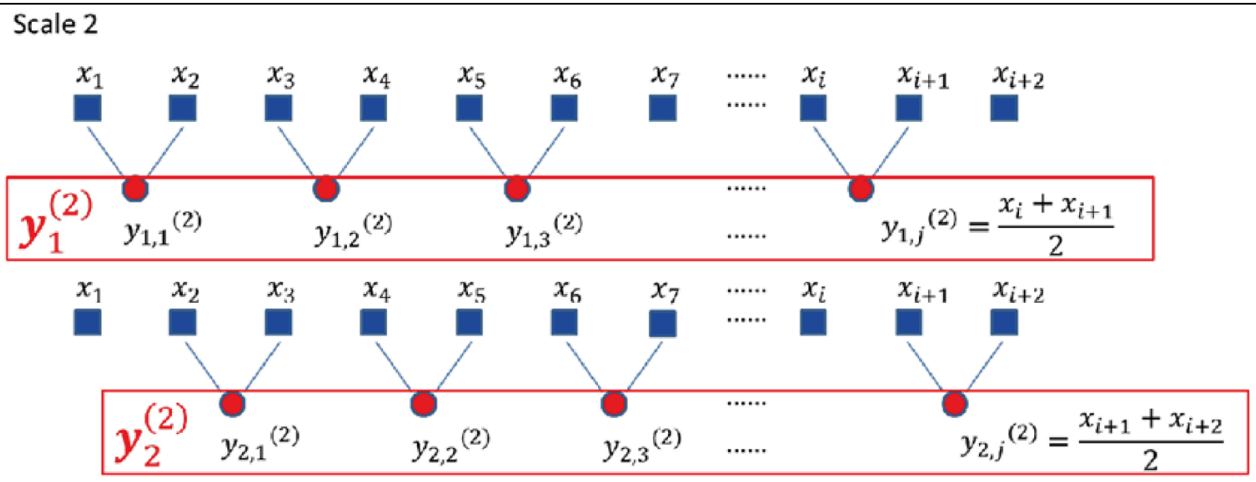

Scale 3
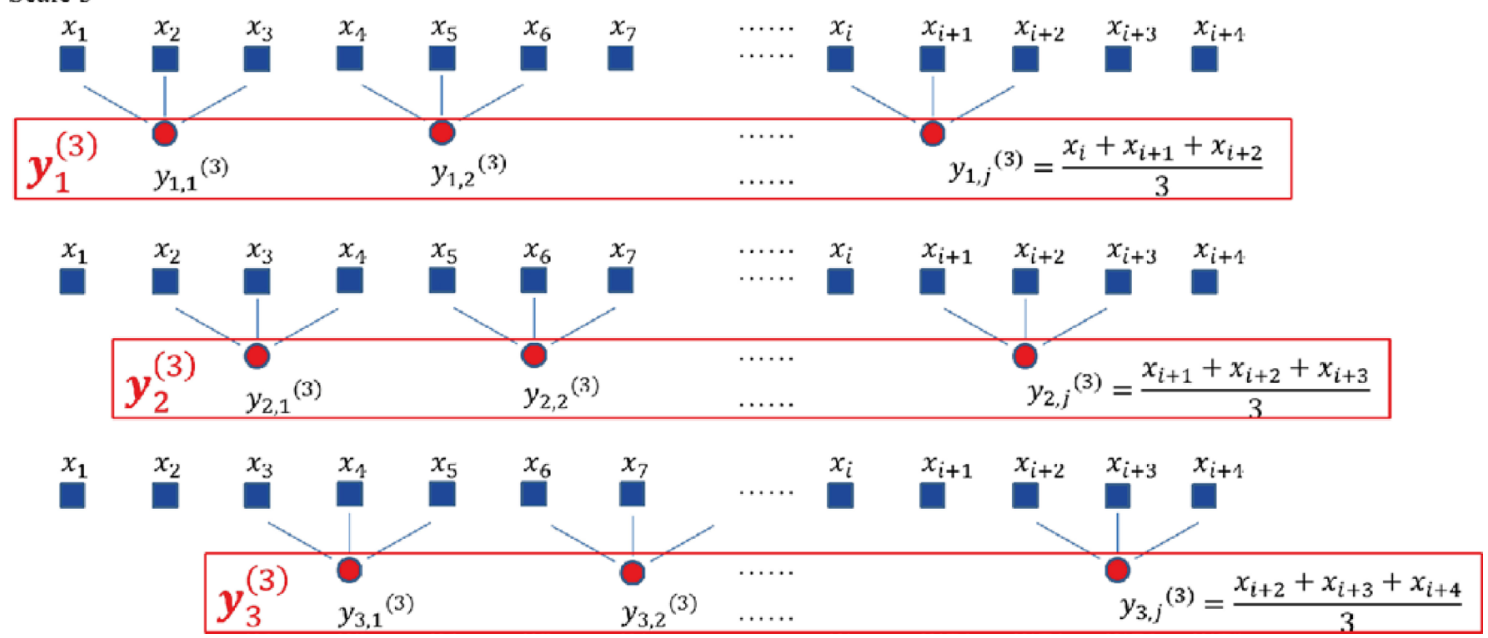

Figure 1. The coarse-grained process of time series. 


\section{RESULTS}

\section{Characteristics of hip flexor and extensor strength of lower extremities}

The hip joint is the main supporting structure of the lower limbs, which is of great significance to the human body's balance and stability. According to the result of the isokinetic test (Table 2), the characteristics of athletes' hip joint muscle strength can be analyzed to understand the characteristics of this project's hip joint muscle strength and provide an individual reference basis for future training.

Through the flexion and extension ability test of the hip joint, it is known that the right flexor strength of the hip joint is slightly greater than the left flexor strength; the right extensor strength is slightly greater than the left extensor strength; the right flexor and extensor force ratio is greater than the left flexor and extensor strength Force ratio; the average power on the right is greater than that on the left; the range of motion on the right is slightly larger than that on the left; at the same speed, the same index on the left and right sides is compared and matched, and there is no significant difference. ${ }^{6}$ At two different test speeds of $60 \% \mathrm{~s}$ (slow speed) and $240 \% \mathrm{~s}$ (fast), there are significant differences in the peak flexion-extension torque per unit weight on the right side and the peak flexion-extension torque per unit weight on the left side. As the speed increases, the test indicators show a decreasing trend. The average power index analyzes the working efficiency of the hip joint muscles, and the degree of hip joint flexion and extension is analyzed by the range of motion. The range of joint motion refers to the angle the joint passes through in one flexion and extension. The average power of left flexion, the average power of right flexion, the average power of left extension, the average power of right extension, and the range of motion on the left showed significant differences as the test speed increased. The average power and range of motion on the right are greater than those on the left. From $\mathrm{P}=\mathrm{W} / \mathrm{T}$, the right hip joint does a lot of work per unit time. From $\mathrm{P}=\mathrm{FV}$, the greater the muscle strength and the greater the movement speed, the greater the power value obtained. The range of motion on the right shows that the value does not decrease as the test speed increases.

The analysis found that the right hip joint flexor strength, extensor strength, and flexor-extensor strength ratio are better than those on the

Table 2. Isokinetic test results of the lower extremity hip joint flexors and extensors of female freestyle skiing aerials.

\begin{tabular}{|c|c|c|c|c|}
\hline \multirow[t]{2}{*}{ Test index } & \multicolumn{2}{|c|}{ Flexor } & \multicolumn{2}{|c|}{ Extensor } \\
\hline & $60 \% / \mathrm{s}$ & $240^{\circ} / \mathrm{s}$ & $60 \% / \mathrm{s}$ & $240^{\circ} / \mathrm{s}$ \\
\hline $\begin{array}{l}\text { Peak torque per unit } \\
\text { weight (left side) } \% \\
\end{array}$ & $1.8 \pm 0.21 \triangle$ & $1.26 \pm 0.37$ & $4.24 \pm 0.78$ 约 & $3.28 \pm 0.43$ 岤 \\
\hline $\begin{array}{l}\text { Peak torque per unit } \\
\text { weight (right side) } \%\end{array}$ & $1.9 \pm 0.16 \triangle$ & $1.44 \pm 0.27$ & $4.33 \pm 0.79$ 本 & $3.26 \pm 0.39$ \\
\hline $\begin{array}{c}\text { Average power } \\
\text { (left side)/W }\end{array}$ & $60.5 \pm 8.97$ & $93.00 \pm 9.01 \triangle$ & $135.6 \pm 14.16$ 访 & $273.16 \pm 18.34$ \\
\hline $\begin{array}{l}\text { Average power } \\
\text { (right side)/W }\end{array}$ & $61.0 \pm 7.16$ & $97.00 \pm 9.83 \triangle$ & $143.8 \pm 16.25$ 하 & 283.33土19.02 \\
\hline $\begin{array}{c}\text { Maximum flexion- } \\
\text { extension ratio } \\
\text { (left side) } \% \\
\end{array}$ & $43.2 \pm 4.96 \triangle$ & $38.48 \pm 6.05$ & $43.2 \pm 4.96 \triangle$ & $38.48 \pm 6.05$ \\
\hline $\begin{array}{c}\text { Maximum flexion- } \\
\text { extension ratio } \\
\text { (right side) } \%\end{array}$ & $44.9 \pm 5.08 \triangle \hat{v}$ & $45.18 \pm 7.29$ 하 & $44.9 \pm 5.08 \triangle$ is & $45.18 \pm 7.29$ 约 \\
\hline $\begin{array}{c}\text { Motion range } \\
\text { (left side) } /^{\circ}\end{array}$ & $78.8 \pm 5.32 \triangle$ & $84.17 \pm 0.75$ & $78.8 \pm 5.32 \triangle$ & $84.17 \pm 0.75$ \\
\hline $\begin{array}{l}\text { Range of motion } \\
\text { (right side) } /{ }^{\circ}\end{array}$ & $85.0 \pm 0.63$ 放 & $85.84 \pm 0.76$ 论 & $85.0 \pm 0.63$ 论 & $85.84 \pm 0.76$ \\
\hline
\end{tabular}

Among them, $\triangle$ means $60^{\circ} / \mathrm{s}$ and $240^{\circ} / \mathrm{s}$ the same index comparison $\mathrm{P}<0.05$, the largest value marked in the two; means the comparison of flexion and extension indexes at $60 \%$ and $240 \% \mathrm{P}<0.05$, marked with the largest value among the two. left side, but there is no significant difference in the muscle strength of the left and right hip joints, which is beneficial for athletes to obtain good stability when landing of. At two different test speeds of $60 \% \mathrm{~s}$ (slow speed) and $240 \%$ s (fast), there are significant differences in the maximum flexion and extension torque per unit weight on the right and the maximum flexion and extension torque per unit weight on the left.? This may be since the large and small muscle groups of the hip joint are fully called in the slow test, but in the fast test, only the large muscle groups are called first.

\section{The characteristics of the flexor and extensor muscles of the lower limbs}

The more load the knee muscles bear, the better its cushioning ability. Knee joint unit peak body weight moment can be a good evaluation of knee joint muscle power and cushioning ability. Therefore, we must study the strength of the muscles at the knee joint to know the knee joint's cushioning capacity. It can be seen from Table 3 that the four index values of the left unit peak weight torque, the correct unit peak weight torque, and the average power on the left and right sides of the extensor are greater than those of the flexors; the left flexor and extensor force ratio and the range of motion are greater than those of the right; $\mathrm{s}$ (slow) and $240 \% \mathrm{~s}$ (fast) at two different test speeds, the left flexor, and extensor strength, the right flexor and extensor strength, and the average power of the left and right sides showed significant differences with the increase of the test speed. ${ }^{8}$ As the test speed increases, the left flexor and right extensor strength decrease with the increase of the test speed, and the right flexor strength and average power increase with the increase of the test speed.

Freestyle skiing aerials require athletes to stretch in the air, and knee joint extensors' strength plays an irreplaceable role here. The analysis found that the left and right extensor power of the knee joint is greater than the flexor power, and the average power of the left and right extensors is greater than the flexor. Extensor power is greater than flexor power, resulting in greater average power of extensors than flexors. The right flexor and extensor muscle strength are greater than that of the left side, and the right knee joint has a stronger cushioning capacity than the left side. The athlete's body support force is distributed to the right knee joint at the moment of

Table 3. Isokinetic test results of the lower limbs knee joint flexors and extensors of female freestyle skiing aerials.

\begin{tabular}{|c|c|c|c|c|}
\hline \multirow{2}{*}{ Test index } & \multicolumn{2}{|c|}{ Flexor } & \multicolumn{2}{|c|}{ Extensor } \\
\hline & $60 \% / \mathrm{s}$ & $240 \% / \mathrm{s}$ & $60 \% / \mathrm{s}$ & $240 \% / \mathrm{s}$ \\
\hline $\begin{array}{c}\text { Peak torque per unit } \\
\text { weight (left side) } \%\end{array}$ & $1.58 \pm 0.26 \triangle$ & $1.23 \pm 0.34$ & $2.43 \pm 0.29 \triangle$ & $1.85 \pm 0.20$ 次 \\
\hline $\begin{array}{l}\text { Peak torque per unit } \\
\text { weight (right side) } \%\end{array}$ & $1.59 \pm 0.22$ & $1.97 \pm 0.26 \triangle$ & $2.84 \pm 0.52 \triangle$ & $1.98 \pm 0.27$ \\
\hline $\begin{array}{c}\text { Average power } \\
\text { (left side) } / \mathrm{W}\end{array}$ & $58.83 \pm 14.00$ & $119.67 \pm 45.45 \triangle$ & $82.83 \pm 28.1$ ك & $204.17 \pm 44.1 \triangle$ \\
\hline $\begin{array}{l}\text { Average power } \\
\text { (right side)/W }\end{array}$ & $53.33 \pm 11.60$ & $112.00 \pm 27.17 \triangle$ & $96.34 \pm 28.4$ 约 & $209.67 \pm 46.21 \triangle$ \\
\hline $\begin{array}{c}\text { Maximum flexion- } \\
\text { extension ratio } \\
\text { (left side) } \%\end{array}$ & $59.63 \pm 11.53$ & $67.69 \pm 17.97$ & $59.63 \pm 11.53$ & $67.69 \pm 17.97$ \\
\hline $\begin{array}{c}\text { Maximum flexion- } \\
\text { extension ratio } \\
\text { (right side) } \%\end{array}$ & $56.41 \pm 9.42$ & $62.05 \pm 8.52$ & $56.41 \pm 9.42$ & $62.05 \pm 8.52$ \\
\hline $\begin{array}{l}\text { Motion range } \\
\text { (left side) } /^{\circ}\end{array}$ & $84.30 \pm 1.75$ & $85.83 \pm 1.47$ & $84.30 \pm 1.75$ & $85.83 \pm 1.47$ \\
\hline $\begin{array}{l}\text { Range of motion } \\
\text { (right side) } /{ }^{\circ}\end{array}$ & $82.50 \pm 4.03$ & $85.84 \pm 1.48$ & $82.50 \pm 4.03$ & $85.84 \pm 1.48$ \\
\hline
\end{tabular}

Note: $\triangle$ means $60^{\circ} / \mathrm{s}$ and $240^{\circ} / \mathrm{s}$ the same index comparison $\mathrm{P}<0.05$, the largest value marked in the two; means the comparison of flexion and extension indexes at $60 \% / \mathrm{s}$ and $240 \% \mathrm{~s} P<0.05$, marked with the largest value among the two. 
landing, and the left knee joint force is small. ${ }^{9}$ At two different test speeds of $60 \%$ s (slow speed) and $240 \%$ (fast), the left flexor and right extensor strength showed that the muscle strength value decreased with the increase of the test speed. This is consistent with the research results of other projects. The average power index increases with the increase of the test speed. From the formula $P=F V$, the power index is proportional to the speed and proportional to the muscle strength. Therefore, it is recommended that athletes improve their body muscle strength when they pay attention to increasing movement speed during regular training.

\section{Characteristics of static balance ability of female athletes}

The human balance ability is generally divided into two types: static balance and dynamic balance. Static balance ability refers to the body's ability to control the center of gravity when the body is in a relatively static state; dynamic balance refers to the body's ability to control the center of gravity and adjust posture during exercise. According to the analysis of the test results (Table 4), the center of gravity's movement distance on the $X$-axis and $Y$-axis is less than that of other situations when the athletes open their eyes normally. When the left leg is closed, the center of gravity moves the longest on the $X$-axis and $Y$-axis. Therefore, it can be inferred that athletes have the best balance when they open their eyes normally. The other conditions are in order of normal linear eye-opening, left open leg eye, right leg open eye, right leg closed eye, and left leg closed eye. The balance is worst when the left leg is closed. The movement distance of the center of gravity on the $Y$-axis is greater than that of the X-axis; in other cases, the center of gravity's movement distance on the $X$-axis is greater than the movement distance of the Y-axis. It shows that the movement distance of the body left and right is greater than the distance moved back and forth under normal eye-opening. In other cases, the body's movement distance in the front and rear directions is greater than the movement distance in the left and right directions..$^{10}$ The speed moment index can judge the changing speed of the athlete's center of gravity on the two axes. It can be seen from the test results that the analysis of the velocity moment is consistent with the above conclusions. Analyzing from the perspective of mechanics, in several cases, the speed moment index is directly related to the distance of the $x$-axis and the change of the $y$-axis. Through the test, we found that the balance of the data obtained by the normal two-foot standing test is greater than that of the one-foot standing.

Table 4. Freestyle skiing aerials ski balance test results.

\begin{tabular}{c|c|c|c}
\hline Test items & $\begin{array}{c}\text { X-axis moving } \\
\text { distance/mm }\end{array}$ & $\begin{array}{c}\text { Y-axis moving } \\
\text { distance/mm }\end{array}$ & $\begin{array}{c}\text { Speed moment/ } \\
\mathbf{m m 2 \cdot s - 1}\end{array}$ \\
\hline Open eyes normally & $110.53 \pm 8.05$ & $112.53 \pm 9.63$ & $6.10 \pm 3.05$ \\
\hline $\begin{array}{c}\text { Normal linear } \\
\text { eye-opening }\end{array}$ & $191.91 \pm 9.82$ & $183.32 \pm 13.8$ & $30.21 \pm 10.94$ \\
\hline Eyes open with left leg & $201.4 \pm 21.14$ & $196.6 \pm 16.89$ & $74.06 \pm 4.34$ \\
\hline Left leg closed eyes & $335.69 \pm 26.57$ & $315.34 \pm 19.56$ & $101.4 \pm 15.78$ \\
\hline Right leg open eyes & $214.4 \pm 21.03$ & $207.4 \pm 16.3$ & $70.21 \pm 6.95$ \\
\hline Right leg closed eyes & $328.03 \pm 25.31$ & $307.82 \pm 15.70$ & $95.95 \pm 8.32$ \\
\hline
\end{tabular}

\section{DISCUSSION}

During the take-off, the athlete's hip joint muscle strength is required to have the ability to bend and straighten the body quickly, and during landing, the athlete's hip joint muscle strength is required to have the ability to control the front hip angle of the body. The range of motion of the joints is related to the amount of body energy obtained during exercise. Athletes need to overcome their gravity to transform their movements when bending to straight. During the exercise, athletes often use left-handed rotation to make the right hip muscle stronger than the left. When the athlete is falling, a situation in which the hip is the axis, and the two feet are the supporting surface formed. If the muscle strength of the left and right sides of the hip joint is greatly different, the center point of the supporting surface may shift, making the gravity moment greater than the muscle torque or less Muscle torque, which will not help athletes to obtain a good body balance. ${ }^{11}$ Therefore, the balance of power on the left and right sides of the athlete's hip joint is helpful for the body balance when landing. Therefore, in normal training, pay attention to the balanced range of motion on the hip joint's left and right sides. The muscle strength of the hip and knee joints play an important role in body support. Freestyle skiing aerials require athletes to have a stable landing. The muscle strength of the hip and knee joints plays a role in completing the action and plays a great role in the landing buffer of freestyle skiing aerials. At the same time, athletes need to coordinate with the hip and knee joints to keep the body in a proper posture and try to take the technical action of landing with both feet at the same time. This is since the supporting surface is relatively large when the feet are standing, the center of gravity of the body is low, and the body's moment of gravity is small. When standing on one foot, the supporting surface area becomes smaller, the center of gravity of the body becomes higher, and the body's moment of gravity becomes larger, resulting in the poor static balance of the body. The balance on the right side of the body is better than that on the left side. It shows that most people's right leg is the main leg, and the right leg has stronger control of muscle strength. Therefore, we make the following suggestions:

Firstly, the right flexor-extensor strength, flexor-extensor strength ratio, and average power value of the hip joint are slightly larger than the left flexor strength. The same index on the left and right sides at the same speed is compared and matched, and there is no significant difference. The four index values of the unit peak moment and average power of the left and right sides of the knee extensor muscles are greater than those of the flexors.

Secondly, at two different test speeds of $60 \%$ s (slow speed) and $240 \% \mathrm{~s}$ (fast), the left flexor and extensor strength, right flexor and extensor strength, and left and right average power increase with the test speed. There is a significant difference. The left and right unit weight peak flexion and extension moments, the left and right unit weight peak flexion and extension moments, the average power of the left and right flexion and extension, and the left motion range showed a significant difference with the increase of test speed, which showed a significant difference with the increase of speed. The test indicators show a decreasing trend. ${ }^{12}$ There was no significant difference in the range of motion on the right as the test speed increased. It shows that the value does not decrease as the test speed increases.

Thirdly, female freestyle skiing aerials should pay attention to reasonable weight control and balanced muscle strength training in their regular training. The dynamic balance ability can be improved by improving the static balance ability. In the case of moderately increasing the exercise speed, strengthen the training of the lower extremity muscle strength. Properly control the hip joint's range of motion to improve the strength of the hip joint flexors and extensors. Moderately increase the maximum extensor strength of the left and right hip joints and the maximum flexor and extensor strength of the right knee joints.

\section{CONCLUSION}

This article believes that the hip flexor and extensor ratio is different for athletes in different sports. For the project of freestyle skiing aerials, 
the hip flexor-extensor power ratio is between 0.43 and 0.52 , which is in line with the characteristics of freestyle skiing aerials that require athletes to have greater strength than flexors. Simultaneously, if the left and right sides of the knee joint have the same strength of flexor and extensor, it will help athletes form a stable gravitational moment and gain body balance. It is recommended that athletes improve their muscle strength while increasing their speed.

The author declare no potential conflict of interest related to this article

AUTHORS' CONTRIBUTIONS: Yanhua Men collated all the experimental data and wrote the manuscript.

\section{REFERENCES}

1. Jadczak $Ł$, Grygorowicz M, Dzudziński W, Śliwowski R. Comparison of static and dynamic balance at different levels of sport competition in professional and junior elite soccer players. J Strength Cond Res. 2019;33(12):3384-91.

2. Yang F, Butler AJ. Efficacy of controlled whole-body vibration training on improving fall risk factors in stroke survivors: a meta-analysis. Neurorehabil Neural Repair. 2020;34(4):275-88.

3. Lipowicz A, Bugdol MN, SzurmikT, Bibrowicz K, Kurzeja P, Mitas AW. Body balance analysis of children and youth with intellectual disabilities. J Intellect Disabil Res. 2019;63(11):1312-23.

4. Taheri $M$, Irandoust $K$. The effect of game-based balance training on body composition and psychomotor performance of obese students. Int J School Health. 2019;6(2):1-4

5. Uspuriene AB, Malinauskas RK, Sniras SA. Effects of education programs on dance sport performance in youth dancers. Eur J Contemp Educ. 2019;8(1):136-43.

6. Acar $\mathrm{H}$, Eler $\mathrm{N}$. The effect of balance exercises on speed and agility in physical education lessons. Universal Journal of Educational Research. 2019;7(1): 74-9.

7. dos Santos KM, Da Roza T, Tonon da Luz SC, Hort JP, Kruger JM, Schevchenco B. Quantification of urinary loss in nulliparous athletes during 1 hour of sports training. American Academy of Physical Medicine and Rehabilitation. 2019;11(5):495-502.
8. Mogharnasi M, TaheriChadorneshin H, Papoli-Baravati SA, Teymuri A. Effects of upper-body resistance exercise training on serum nesfatin-1 level, insulin resistance, and body composition in obese paraplegic men. Disabil Health J. 2019;12(1):29-34.

9. Farkhodovich IB. Development of balance in young kayakers in the initial stage of training. European Journal of Research and Reflection in Educational Sciences. 2020 [cited 202121 Jun];8(2):66-70. Available from: https://www.idpublications.org/wp-content/uploads/2020/02/Full-Paper-DEVELOPMENT-OF-BALANCE-IN-YOUNG-KAYAKERS-IN-THE-INITIAL-STAGE-OF-TRAINING.pdf

10. Moya-Nájera D, Moya-Herraiz Á, Gargallo P, Calatayud J, Escrig-Sos J, Colado JC. Clinical relevance of a balance training program on liver transplant patients. A randomized controlled trial. Transplantation. 2019 [cited 202121 Jun];103(5):965-72. Available from: https://europepmc. org/article/med/30113994

11. Karim A, Roddey T, Mitchell K, Ortiz A, Olson S. Immediate effect of whole body vibration on saute height and balance in female professional contemporary dancers a randomized controlled trial. J Dance Med Sci. 2019;23(1):3-10.

12. Bouteraa I, Negra Y, Shephard RJ, Chelly MS. Effects of combined balance and plyometric training on athletic performance in female basketball players. J Strength Cond Res. 2020;34(7):1967-73. 